\title{
Association of VEGF haplotypes with breast cancer risk in North-West Indians
}

\author{
Vasudha Sambyal ${ }^{1}$, Kamlesh Guleria ${ }^{* *} \mathbb{0}$, Ruhi Kapahi ${ }^{1}$, Mridu Manjari ${ }^{2}$, Meena Sudan ${ }^{3}$, Manjit Singh Uppal ${ }^{4}$ and \\ Neeti Rajan Singh ${ }^{4}$
}

\begin{abstract}
Background: Angiogenesis is a complex and coordinated process regulated by different growth factors and is one of the hallmark features of cancer. VEGF is one of the most important endothelial cell mitogen and has a critical role in normal physiological and tumor angiogenesis. The objective of this study was to investigate the potential association of haplotypes of six VEGF polymorphisms with breast cancer risk in North-West Indians.
\end{abstract}

Methods: Samples of 250 breast cancer patients and 250 age and sex matched controls were genotyped for VEGF $-2578 \mathrm{C} / \mathrm{A},-2549 \mathrm{I} / \mathrm{D},-460 \mathrm{~T} / \mathrm{C},+405 \mathrm{C} / \mathrm{G},-7 \mathrm{C} / \mathrm{T}$ and $+936 \mathrm{C} / \mathrm{T}$ polymorphisms. Haplotypes were generated to determine the better contribution of VEGF polymorphisms to breast cancer risk.

Results: Haplotypes CDTCCC $(\mathrm{OR}=0.56,95 \% \mathrm{Cl}, 0.38-0.81 ; p=0.003)$ and CDTGCC $(\mathrm{OR}=0.63,95 \% \mathrm{Cl}, 0.44-0.92$; $p=0.018)$ of $V E G F-2578 \mathrm{C} / \mathrm{A},-2549 \mathrm{I} / \mathrm{D},-460 \mathrm{~T} / \mathrm{C},+405 \mathrm{C} / \mathrm{G},-7 \mathrm{C} / \mathrm{T}$ and $+936 \mathrm{C} / \mathrm{T}$ polymorphisms were significantly associated with decreased risk of breast cancer. CDTCCC haplotype was also significantly associated with reduced risk of breast cancer in pre and post menopausal as well as both obese and non obese patients. Haplotype CDTGCC was marginally associated ( $p=0.07$ ) with reduced risk of breast cancer in non-obese patients as compared with nonobese controls where as haplotype AICGTC was marginally associated $(p=0.09)$ with reduced risk of breast cancer in obese patients when compared with non-obese patients. The CDTGCC haplotype was significantly associated with increased risk of breast cancer in premenopausal obese patients $(\mathrm{OR}=1.98,95 \% \mathrm{Cl}, 1.10-3.56 ; p=0.02)$.

Conclusions: Our data indicated that CDTCCC and CDTGCC haplotypes of VEGF -2578C/A, -25491/D, -460T/C, $+405 \mathrm{C} / \mathrm{G},-7 \mathrm{C} / \mathrm{T}$ and $+936 \mathrm{C} / \mathrm{T}$ polymorphisms were significantly associated with breast cancer risk in North-West Indians. Further studies on multiethnic groups with larger sample size are required to confirm our results.

Keywords: VEGF, Polymorphism, Haplotype, Breast cancer

\section{Background}

Angiogenesis is one of the hallmark features of cancer [1]. It is a complex and coordinated process regulated by different growth factors like platelet derived growth factor, transforming growth factor and angiopoietins among which vascular endothelial growth factors (VEGF) play a crucial role [2-4]. VEGF is one of the most powerful

\footnotetext{
*Correspondence: guleria_k@yahoo.com

1 Human Cytogenetics Laboratory, Department of Human Genetics, Guru Nanak Dev University, Amritsar 143005, Punjab, India

Full list of author information is available at the end of the article
}

endothelial cell mitogen and has a very critical role in normal physiological and tumor angiogenesis [5-7]. It enhances tumor vessel permeability and endothelial cell proliferation, migration, differentiation, capillary formation and also has proinflammatory actions [8-12].

The VEGFA also known as VEGF is located at $6 \mathrm{p} 21.3$ and it comprises eight exons and seven introns (Fig. 1) [13]. It is highly polymorphic with several polymorphisms in the promoter, $5^{\prime}$-untranslated region $\left(5^{\prime}\right.$ UTR) and $3^{\prime}$-UTR [14, 15]. Polymorphisms in the promoter and UTRs have been reported to regulate 


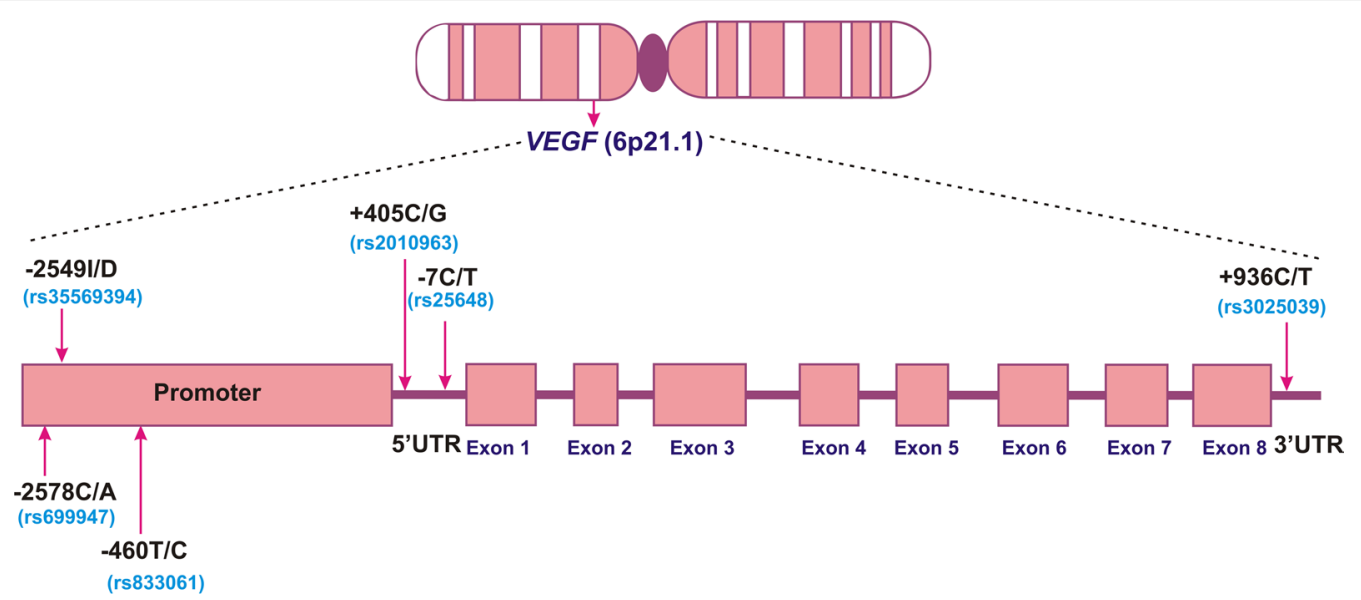

Fig. 1 Schematic diagram showing chromosomal position of VEGF and locations of analyzed polymorphisms

VEGF expression via alternative initiation of transcription and internal initiation of translation [16, 17]. Functional genetic polymorphisms which alter the regulation of gene expression are predicted to have a significant impact on disease pathogenesis [18]. VEGF $-2578 \mathrm{C} / \mathrm{A},-2549 \mathrm{I} / \mathrm{D},-460 \mathrm{~T} / \mathrm{C},-116 \mathrm{G} / \mathrm{A},+405 \mathrm{C} / \mathrm{G}$ and $+936 \mathrm{C} / \mathrm{T}$ polymorphisms have been associated with differential expression of VEGF [14, 15, 19-22]. The importance of VEGFA in breast cancer has been described in several studies [23, 24]. Increased expression of VEGF has been documented in invasive and non invasive breast cancer tissue $[25,26]$. Polymorphisms in promoter, $5^{\prime}$-UTR and $3^{\prime}$-UTR of VEGF have been reported to affect translation efficiency, circulating plasma concentrations and tumor tissue expression of VEGF $[19,27]$. It has been documented that VEGF polymorphisms influencing VEGF expression in normal cells might have an impact on tumorigenesis, tumor progression, and response to anti-VEGF agents [22, 28-30].

Haplotype analysis could be a better predictive approach rather than investigating individual polymorphism. It estimates more specific risk and reduces the dimension of association tests and increase statistical power [31]. Due to the important role of $V E G F$ in carcinogenesis, the present study aimed to investigate the association of haplotypes of $V E G F$ $-2578 \mathrm{C} / \mathrm{A} \quad(-1540 \mathrm{C} / \mathrm{A}), \quad-2549 \mathrm{I} / \mathrm{D} \quad(-1511 \mathrm{I} / \mathrm{D})$, $-460 \mathrm{~T} / \mathrm{C}(-1498 \mathrm{~T} / \mathrm{C}),+405 \mathrm{C} / \mathrm{G}(-634 \mathrm{C} / \mathrm{G}),-7 \mathrm{C} / \mathrm{T}$ $(+1032 \mathrm{C} / \mathrm{T})$ and $+936 \mathrm{C} / \mathrm{T}$ polymorphisms with breast cancer risk in North-West Indians. So far there is no combined report on these six VEGF polymorphisms in breast cancer. To the best of our knowledge, this is the first study evaluating the potential association of haplotypes of VEGF -2578C/A (rs699947),
-2549I/D (rs35569394), -460T/C (rs833061), $+405 \mathrm{C} / \mathrm{G}(\mathrm{rs} 2010963)-7 \mathrm{C} / \mathrm{T}(\mathrm{rs} 25648)$ and $+936 \mathrm{C} / \mathrm{T}$ (rs3025039) polymorphism with breast cancer risk.

\section{Methods}

\section{Subjects}

The study was performed according to Declaration of Helsinki and was approved by the Ethics Committee of Guru Nanak Dev University, Amritsar, Punjab, India. All the subjects gave a written informed consent with a signature or thumb impression. A total of 500 subjects (250 breast cancer patients and 250 healthy controls) were analyzed in this study. The patients were investigated at Sri Guru Ram Das Institute of Medical Sciences and Research, Vallah, Amritsar, Punjab (India). The selection criteria of patients and controls have been described in our previous study [32]. All the subjects gave $5 \mathrm{ml}$ blood samples for genetic analyses.

\section{Genotyping of VEGF polymorphisms and analyses of data}

The DNA was extracted from EDTA-anti-coagulated blood samples using organic method [33] with few modifications. Three promoter (VEGF $-2578 \mathrm{C} / \mathrm{A},-2549 \mathrm{I} / \mathrm{D}$, $-460 \mathrm{~T} / \mathrm{C})$, two $5^{\prime}-\mathrm{UTR}(+405 \mathrm{C} / \mathrm{G},-7 \mathrm{C} / \mathrm{T})$, and one 3 '-UTR $(+936 \mathrm{C} / \mathrm{T})$ polymorphisms were analyzed in this study (Fig. 1). The VEGF -2549I/D polymorphism was analyzed by direct PCR. VEGF $-460 \mathrm{~T} / \mathrm{C},-2578 \mathrm{C} / \mathrm{A}$ $+405 \mathrm{C} / \mathrm{G}$ and $V E G F+936 \mathrm{C} / \mathrm{T}$ polymorphisms of $V E G F$ were analyzed using PCR-RFLP method. $V E G F-7 \mathrm{C} / \mathrm{T}$ polymorphism was analyzed by ARMS-PCR. Ten percent of randomly selected samples were sequenced to validate the PCR based assay genotyping and results of both sets of analyses were $100 \%$ concordant. The detail of reaction conditions and analysis of genotype data have been described in our published studies $[34,35]$. To determine 
the better contribution of $V E G F$ polymorphisms to breast cancer risk, haplotypes of six VEGF polymorphisms were generated using the online SNPStats software [36]. Further we predicted the possible influence of studied VEGF polymorphisms on the transcription factor binding sites using online software TFSEARCH (http://www.cbrc.jp/ research/db/TFSEARCH.html).

\section{Results}

\section{Characteristics of study participants}

The demographic characteristics of study participants were presented in Table 1 . The mean age of patients was $49.38 \pm 11.87$ years and of controls was $49.34 \pm 11.85$ years. Of the 250 breast cancer patients, 234 (93\%) had infiltrating ductal carcinoma, 4 (2\%) had infiltrating lobular carcinoma and $12(5 \%)$ had other

Table 1 Characteristics of Breast cancer patients and healthy controls

\begin{tabular}{|c|c|c|c|c|}
\hline Variable & $\begin{array}{l}\text { Patients } \\
\mathrm{n}\end{array}$ & $\%$ & $\begin{array}{l}\text { Controls } \\
\mathrm{n}\end{array}$ & $\%$ \\
\hline Total No. of subjects & 250 & & 250 & \\
\hline \multicolumn{5}{|l|}{ Sex } \\
\hline Males & 7 & 2.8 & 7 & 2.8 \\
\hline Females & 243 & 97.2 & 243 & 97.2 \\
\hline \multicolumn{5}{|l|}{ Age at diagnosis (years) } \\
\hline$\leq 40$ & 66 & 26.4 & 66 & 26.4 \\
\hline$>40$ & 184 & 73.6 & 184 & 73.6 \\
\hline Mean age & $49.38 \pm 11.87$ & & $49.34 \pm 11.85$ & \\
\hline Range & $25-85$ & & $25-85$ & \\
\hline \multicolumn{5}{|l|}{ Habitat } \\
\hline Rural & 186 & 74.4 & 186 & 74.4 \\
\hline Urban & 64 & 25.6 & 64 & 25.6 \\
\hline \multicolumn{5}{|l|}{ Diet } \\
\hline Vegetarian & 147 & 58.8 & 154 & 61.6 \\
\hline Non vegetarian & 103 & 41.2 & 96 & 38.4 \\
\hline \multicolumn{5}{|l|}{ Obesity } \\
\hline Non obese & 62 & 24.8 & 70 & 28.0 \\
\hline Obese & 188 & 75.2 & 180 & 72.0 \\
\hline \multicolumn{5}{|l|}{ Menstrual status } \\
\hline Premenopausal & 114 & 46.91 & 150 & 61.73 \\
\hline Postmenopausal & 129 & 53.09 & 93 & 38.27 \\
\hline Mean age at menarche & $14.74 \pm 1.78$ & & $14.75 \pm 1.47$ & \\
\hline $\begin{array}{l}\text { Mean age at first child } \\
\text { birth }\end{array}$ & $22.70 \pm 4.08$ & & $22.45 \pm 3.43$ & \\
\hline \multicolumn{5}{|l|}{ Breastfeeding } \\
\hline Yes & 215 & 88.48 & 224 & 92.18 \\
\hline No & 28 & 11.52 & 19 & 7.82 \\
\hline \multicolumn{5}{|l|}{ Oral Contraceptives } \\
\hline Yes & 21 & 8.64 & 16 & 6.58 \\
\hline No & 222 & 91.36 & 227 & 93.42 \\
\hline
\end{tabular}

types of cancer like medullary carcinoma, mucinous carcinoma, Paget's disease and phyllodes tumor. In the present study, 127 (51\%) cases had tumor in left breast, 112 $(45 \%)$ in right breast and $11(4 \%)$ cases had tumor in both breasts. Of the 250 breast cancer patients, 65 (26\%) had stage I, 119 (48\%) had stage II, 48 (19\%) had stage III, and $18(7 \%)$ had stage IV tumor.

\section{Association of VEGF polymorphisms with breast cancer}

The results of association of individual VEGF polymorphism were summarized (Additional file 1: Table S1). The AA genotype and A allele of $V E G F-2578 \mathrm{C} / \mathrm{A}$, II genotype and I allele of $V E G F-2549 \mathrm{I} / \mathrm{D}, \mathrm{CC}$ genotype and C allele of $V E G F-460 \mathrm{~T} / \mathrm{C}$, GG genotype and G allele of $V E G F+405 \mathrm{C} / \mathrm{G}$ polymorphism was significantly associated with increased risk of breast cancer. No association of $V E G F-7 \mathrm{C} / \mathrm{T}$ and $+936 \mathrm{C} / \mathrm{T}$ polymorphism with breast cancer risk was observed. We analyzed haplotypes of $V E G F-2578 \mathrm{C} / \mathrm{A},-2549 \mathrm{I} / \mathrm{D},-460 \mathrm{~T} / \mathrm{C},+405 \mathrm{C} / \mathrm{G}$, $-7 \mathrm{C} / \mathrm{T}$ and $+936 \mathrm{C} / \mathrm{T}$ polymorphisms to determine if there is any difference in VEGF haplotypes between breast cancer patients and healthy controls. The most common haplotype in the present study was AICGCC, with the frequencies of $31.3 \%$ in breast cancer patients and $23.8 \%$ in healthy control individuals. We observed that CDTCCC $(\mathrm{OR}=0.56,95 \% \mathrm{CI}, 0.38-0.81 ; p=0.003)$ and CDTGCC (OR $=0.63,95 \% \mathrm{CI}, 0.44-0.92 ; p=0.018)$ haplotypes were significantly associated with decreased risk of breast cancer (Table 2). CDTCCC haplotype was significantly associated with reduced risk of breast cancer in pre and post menopausal patients (Tables 3 and 4). None of the VEGF haplotype was associated with breast cancer risk in pre menopausal patients when compared with post menopausal patients (Table 5). The CDTCCC haplotype was also significantly associated with decreased risk of breast cancer in both obese and

Table 2 Association between VEGF haplotypes and breast cancer risk

\begin{tabular}{lllll}
\hline Haplotype $^{\text {a }}$ & Cases (\%) & Controls (\%) & OR(95\%Cl) & $\boldsymbol{p}$ value \\
\hline AICGCC & 31.3 & 23.8 & 1 (Reference) & \\
CDTCCC & 23.7 & 28.9 & $0.56(0.38-0.81)$ & $\mathbf{0 . 0 0 3}$ \\
CDTGCC & 19.6 & 25.6 & $0.63(0.44-0.92)$ & $\mathbf{0 . 0 1 8}$ \\
AICGTC & 9.0 & 9.3 & $0.75(0.43-1.30)$ & 0.31 \\
AICGCT & 3.1 & 1.8 & $1.22(0.40-3.74)$ & 0.73 \\
AICGTT & 1.8 & 2.0 & $0.76(0.25-2.33)$ & 0.64 \\
CDTCCT & 1.7 & 1.2 & $1.25(0.30-5.19)$ & 0.76 \\
CDTGCT & 1.4 & 1.5 & $0.65(0.13-3.35)$ & 0.61 \\
\hline
\end{tabular}

Significant $p$ values are shown in bold

$O R$ odds ratio, $\mathrm{Cl}$ confidence interval

${ }^{a}$ In order of $-2578 \mathrm{C} / \mathrm{A},-2549 \mathrm{I} / \mathrm{D},-460 \mathrm{~T} / \mathrm{C},+405 \mathrm{C} / \mathrm{G},-7 \mathrm{C} / \mathrm{T}$ and $+936 \mathrm{C} / \mathrm{T}$ 
Table 3 VEGF haplotypes and breast cancer risk in premenopausal subjects

\begin{tabular}{|c|c|c|c|c|}
\hline Haplotype $^{a}$ & $\begin{array}{l}\text { Pre } \\
\text { menopausal } \\
\text { cases }(\%) \\
n=114\end{array}$ & $\begin{array}{l}\text { Pre } \\
\text { menopausal } \\
\text { controls (\%) } \\
n=150\end{array}$ & OR $(95 \% \mathrm{Cl})$ & $p$ value \\
\hline AICGCC & 29.0 & 24.5 & 1 (Reference) & \\
\hline CDTCCC & 20.6 & 28.5 & $\begin{array}{l}0.65(0.43- \\
0.99)\end{array}$ & 0.04 \\
\hline CDTGCC & 25.0 & 26.3 & $\begin{array}{l}0.95(0.64- \\
1.42)\end{array}$ & 0.81 \\
\hline AICGTC & 9.0 & 9.9 & $\begin{array}{l}0.90(0.50- \\
1.64)\end{array}$ & 0.73 \\
\hline AICGCT & 3.1 & 1.4 & $\begin{array}{l}2.23(0.67- \\
7.43)\end{array}$ & 0.18 \\
\hline AICGTT & 3.2 & 1.5 & $\begin{array}{l}2.27(0.69- \\
7.51)\end{array}$ & 0.16 \\
\hline CDTCCT & 3.3 & 2.1 & $\begin{array}{l}1.87(0.46- \\
7.56)\end{array}$ & 0.38 \\
\hline
\end{tabular}

Significant $p$ values are shown in bold

$O R$ odds ratio, $\mathrm{Cl}$ confidence interval

${ }^{a}$ In order of $-2578 \mathrm{C} / \mathrm{A},-2549 \mathrm{I} / \mathrm{D},-460 \mathrm{~T} / \mathrm{C},+405 \mathrm{C} / \mathrm{G},-7 \mathrm{C} / \mathrm{T}$ and $+936 \mathrm{C} / \mathrm{T}$

Table 4 VEGF haplotype and breast cancer risk in post menopausal subjects

\begin{tabular}{|c|c|c|c|c|}
\hline Haplotype $^{a}$ & $\begin{array}{l}\text { Post } \\
\text { menopausal } \\
\text { cases }(\%) \\
n=129\end{array}$ & $\begin{array}{l}\text { Post } \\
\text { menopausal } \\
\text { controls (\%) } \\
n=93\end{array}$ & OR $(95 \% \mathrm{Cl})$ & $p$ value \\
\hline AICGCC & 31.9 & 23.4 & 1 (Reference) & \\
\hline CDTCCC & 24.8 & 33.3 & $\begin{array}{l}0.52(0.30- \\
0.92)\end{array}$ & 0.02 \\
\hline CDTGCC & 17.6 & 22.4 & $\begin{array}{l}0.59(0.31- \\
1.12)\end{array}$ & 0.11 \\
\hline AICGTC & 9.2 & 7.9 & $\begin{array}{l}0.82(0.34- \\
1.99)\end{array}$ & 0.66 \\
\hline AICGCT & 3.3 & 2.4 & $\begin{array}{l}1.05(0.16- \\
6.83)\end{array}$ & 0.96 \\
\hline AICGTT & 0.7 & 3.3 & $\begin{array}{l}0.27(0.04- \\
1.94)\end{array}$ & 0.19 \\
\hline
\end{tabular}

Significant $p$ values are shown in bold

$O R$ odds ratio, $\mathrm{Cl}$ confidence interval

a In order of $-2578 \mathrm{C} / \mathrm{A},-2549 \mathrm{I} / \mathrm{D},-460 \mathrm{~T} / \mathrm{C},+405 \mathrm{C} / \mathrm{G},-7 \mathrm{C} / \mathrm{T}$ and $+936 \mathrm{C} / \mathrm{T}$

non obese patients (Tables 6 and 7). Haplotype CDTGCC was marginally associated $(p=0.07)$ with reduced risk of breast cancer in non-obese patients as compared with non-obese controls (Table 7) where as haplotype AICGTC was marginally associated $(p=0.09)$ with reduced risk of breast cancer in obese patients when compared with non-obese patients (Table 8). Further we compared pre menopausal obese patients with post menopausal obese patients and observed that CDTGCC
Table 5 Association of VEGF haplotypes with breast cancer risk in pre menopausal and post menopausal patients

\begin{tabular}{lllll}
\hline Haplotype $^{\mathbf{a}}$ & $\begin{array}{l}\text { Pre } \\
\text { menopausal } \\
(\mathbf{\%}) \\
\mathbf{n = 1 1 4}\end{array}$ & $\begin{array}{l}\text { Post } \\
\text { menopausal } \\
\mathbf{( \% )} \\
\mathbf{n}=\mathbf{1 2 9}\end{array}$ & OR (95\%Cl) & $\boldsymbol{p}$ value \\
\hline AICGCC & 29.0 & 31.9 & 1 (Reference) & \\
CDTCCC & 20.6 & 24.8 & $0.95(0.54-1.67)$ & 0.86 \\
CDTGCC & 25.0 & 17.6 & $1.42(0.82-2.47)$ & 0.22 \\
AICGTC & 9.0 & 9.2 & $1.05(0.48-2.33)$ & 0.90 \\
AICGCT & 3.1 & 3.3 & $0.70(0.12-3.90)$ & 0.68 \\
CDTCCT & 3.8 & 1.1 & $3.01(0.55-16.65)$ & 0.21 \\
AITGTC & 2.8 & 1.8 & $0.24(0.03-1.97)$ & 0.18 \\
AITGCC & 1.5 & 1.2 & $1.31(0.29-5.96)$ & 0.73 \\
\hline
\end{tabular}

$O R$ odds ratio, $\mathrm{Cl}$ confidence interval

${ }^{\mathrm{a}}$ In order of $-2578 \mathrm{C} / \mathrm{A},-2549 \mathrm{I} / \mathrm{D},-460 \mathrm{~T} / \mathrm{C},+405 \mathrm{C} / \mathrm{G},-7 \mathrm{C} / \mathrm{T}$ and $+936 \mathrm{C} / \mathrm{T}$

Table6 Association of VEGF haplotypes with breast cancer risk in obese subjects

\begin{tabular}{lllll}
\hline Haplotype $^{\text {a }}$ & $\begin{array}{l}\text { Obese } \\
\text { patients } \\
(\mathbf{\%}) \\
\mathbf{n = 1 8 8}\end{array}$ & $\begin{array}{l}\text { Obese } \\
\text { controls } \\
\mathbf{( \% )} \\
\mathbf{n = 1 8 0}\end{array}$ & OR $(\mathbf{9 5 \%} \mathbf{1 8})$ & $\boldsymbol{p}$ value \\
\hline AICGCC & 31.2 & 24.6 & 1 (Reference) & \\
CDTCCC & 25.2 & 28.9 & $0.63(0.41-0.99)$ & $\mathbf{0 . 0 4}$ \\
CDTGCC & 19.3 & 25.0 & $0.76(0.49-1.19)$ & 0.23 \\
AICGTC & 7.0 & 9.3 & $0.70(0.35-1.39)$ & 0.31 \\
AICGTT & 3.0 & 1.9 & $1.27(0.39-4.12)$ & 0.69 \\
CDTGCT & 2.4 & 1.7 & $1.23(0.29-5.22)$ & 0.78 \\
AICGCT & 1.8 & 1.7 & $0.77(0.14-4.26)$ & 0.76 \\
CDTCCT & 1.8 & 1.5 & $1.17(0.26-5.18)$ & 0.84 \\
\hline
\end{tabular}

Significant $p$ values are shown in bold

$O R$ odds ratio, $\mathrm{Cl}$ confidence interval

${ }^{\mathrm{a}}$ In order of $-2578 \mathrm{C} / \mathrm{A},-2549 \mathrm{I} / \mathrm{D},-460 \mathrm{~T} / \mathrm{C},+405 \mathrm{C} / \mathrm{G},-7 \mathrm{C} / \mathrm{T}$ and $+936 \mathrm{C} / \mathrm{T}$

Table 7 Association of VEGF haplotypes with breast cancer risk in non obese subjects

\begin{tabular}{lllll}
\hline Haplotype $^{\mathbf{a}}$ & $\begin{array}{l}\text { Non-obese } \\
\text { patients (\%) } \\
\mathbf{n}=\mathbf{6 2}\end{array}$ & $\begin{array}{l}\text { Non-obese } \\
\text { controls (\%) } \\
\mathbf{n}=\mathbf{7 0}\end{array}$ & OR(95\%Cl) & $\boldsymbol{p}$ value \\
\hline AICGCC & 34.1 & 23.7 & 1 (Reference) & \\
CDTCCC & 20.9 & 31.2 & $0.44(0.21-0.93)$ & $\mathbf{0 . 0 3}$ \\
CDTGCC & 18.2 & 22.7 & $0.47(0.21-1.05)$ & 0.07 \\
AICGTC & 13.5 & 9.5 & $1.11(0.38-3.21)$ & 0.85 \\
CDTGTC & 1.2 & 1.4 & $0.46(0.02-12.99)$ & 0.65 \\
\hline
\end{tabular}

Significant $p$ values are shown in bold

$O R$ odds ratio, $\mathrm{Cl}$ confidence interval

a In order of $-2578 \mathrm{C} / \mathrm{A},-2549 \mathrm{I} / \mathrm{D},-460 \mathrm{~T} / \mathrm{C},+405 \mathrm{C} / \mathrm{G},-7 \mathrm{C} / \mathrm{T}$ and $+936 \mathrm{C} / \mathrm{T}$ 
Table 8 Association of VEGF haplotypes with breast cancer risk in obese and non obese patients

\begin{tabular}{lllll}
\hline Haplotype $^{\mathbf{a}}$ & $\begin{array}{l}\text { Obese (\%) } \\
\mathbf{n = 1 8 8}\end{array}$ & $\begin{array}{l}\text { Non-obese (\%) } \\
\mathbf{n = 6 2}\end{array}$ & OR (95\%Cl) & $\boldsymbol{p}$ value \\
\hline AICGCC & 31.2 & 34.1 & 1 (Reference) & \\
CDTCCC & 25.1 & 20.9 & $1.28(0.70-2.34)$ & 0.42 \\
CDTGCC & 19.3 & 18.2 & $1.11(0.61-2.03)$ & 0.73 \\
AICGTC & 7.0 & 13.5 & $0.48(0.21-1.12)$ & 0.09 \\
CDTGTC & 3.1 & 1.2 & $2.74(0.33-$ & 0.35 \\
& & & $22.40)$ & \\
AICGCT & 1.8 & 4.8 & $0.27(0.04-1.91)$ & 0.19 \\
\hline
\end{tabular}

OR odds ratio, $\mathrm{Cl}$ confidence interval

${ }^{\mathrm{a}}$ In order of $-2578 \mathrm{C} / \mathrm{A},-2549 \mathrm{I} / \mathrm{D},-460 \mathrm{~T} / \mathrm{C},+405 \mathrm{C} / \mathrm{G},-7 \mathrm{C} / \mathrm{T}$ and $+936 \mathrm{C} / \mathrm{T}$

Table 9 Association of VEGF haplotypes with breast cancer risk in pre menopausal obese and post menopausal obese patients

\begin{tabular}{lllll}
\hline Haplotype $^{\mathbf{a}}$ & $\begin{array}{l}\text { Pre } \\
\text { menopausal } \\
\text { obese }(\%) \\
\mathbf{n = 8 5}\end{array}$ & $\begin{array}{l}\text { Post } \\
\text { menopausal } \\
\text { obese (\%) } \\
\mathbf{n = 1 0 2}\end{array}$ & OR (95\%Cl) & $\boldsymbol{p}$ value \\
\hline AICGCC & 25.0 & 35.1 & 1 (Reference) & \\
CDTCCC & 21.8 & 25.5 & $1.13(0.60-2.13)$ & 0.7 \\
CDTGCC & 27.6 & 15.0 & $1.98(1.10-3.56)$ & $\mathbf{0 . 0 2}$ \\
CDTGCT & 1.8 & 2.7 & $1.45(0.27-7.71)$ & 0.66 \\
AICGTC & 8.6 & 7.9 & $1.27(0.50-3.24)$ & 0.62 \\
\hline
\end{tabular}

Significant $p$ values are shown in bold

$O R$ odds ratio, $\mathrm{Cl}$ confidence interval

${ }^{\mathrm{a}}$ In order of $-2578 \mathrm{C} / \mathrm{A},-2549 \mathrm{I} / \mathrm{D},-460 \mathrm{~T} / \mathrm{C},+405 \mathrm{C} / \mathrm{G},-7 \mathrm{C} / \mathrm{T}$ and $+936 \mathrm{C} / \mathrm{T}$

haplotype was significantly associated $(p=0.02)$ with increased risk of breast cancer in premenopausal obese patients (Table 9).

The TFSEARCH software was used to predict the functional significance of $V E G F$ polymorphisms. Based on the difference in TFSEARCH TFBS scores, VEGF -2578C/A and $+405 \mathrm{C} / \mathrm{G}$ polymorphisms were predicted to alter a transcription factor binding site. VEGF -2578A allele abolish the binding site of GATA-2 transcription factor where as $V E G F+405 \mathrm{G}$ allele created the binding site of MZF1 (Myeloid zinc finger 1) transcription factor.

\section{Discussion}

In the present study we investigated the potential association of VEGF haplotypes based on six polymorphisms with breast cancer risk. In previous reported studies, by using the single/double or triple polymorphism approach, VEGF $-2578 \mathrm{C} / \mathrm{A},-2549 \mathrm{I} / \mathrm{D},-460 \mathrm{~T} /$ $\mathrm{C},+405 \mathrm{C} / \mathrm{G},-7 \mathrm{C} / \mathrm{T}$ and $+936 \mathrm{C} / \mathrm{T}$ polymorphisms have been analyzed to evaluate their potential association with breast cancer risk in different ethnic groups and results are conflicting (Additional file 1: Table S2).
The ethnicity difference and inadequate sample size could be the potential cause of inconsistent results.

In the present study, we observed that CDTCCC $(\mathrm{OR}=0.56,95 \% \mathrm{CI}, 0.38-0.81 ; p=0.003)$ and CDT$\mathrm{GCC}(\mathrm{OR}=0.63,95 \% \mathrm{CI}, 0.44-0.92 ; p=0.018)$ haplotypes of $V E G F-2578 \mathrm{C} / \mathrm{A},-2549 \mathrm{I} / \mathrm{D},-460 \mathrm{~T} / \mathrm{C}$, $+405 \mathrm{C} / \mathrm{G},-7 \mathrm{C} / \mathrm{T}$ and $+936 \mathrm{C} / \mathrm{T}$ polymorphisms were significantly associated with reduced risk of breast cancer. In none of the previous studies, these six polymorphisms have been reported together. In Caucasian subjects, $-460 \mathrm{~T} / 405 \mathrm{C} /-7 \mathrm{C} /$, $+936 \mathrm{C}$ haplotype was associated with reduced risk of breast cancer [46]. Significant association of $V E G F-2578 \mathrm{~A} /-1154 \mathrm{~A} /+405 \mathrm{G}$ haplotype with decreased risk of invasive breast cancer has been reported in American population [44]. Haplotype $V E G F-1154 \mathrm{~A} /-2578 \mathrm{~A} /-634 \mathrm{G} /-460 \mathrm{C}$ was associated with decreased risk of breast cancer in Moroccan population [39]. The $-2578 \mathrm{~A} /-1154 \mathrm{G} /+405 \mathrm{G}$ haplotype was associated with decreased risk whereas haplotype $-2578 \mathrm{C} /-1154 \mathrm{G} / 405 \mathrm{G}$ was associated with increased risk of breast cancer recurrence in Caucasian women [58]. Association of $-2578 \mathrm{C} /+405 \mathrm{C}$ haplotype with tumor size and higher histological grade has been documented in breast cancer patients [45]. None of the haplotype of $V E G F-2578 \mathrm{C} / \mathrm{A},-2549 \mathrm{I} / \mathrm{D},-460 \mathrm{~T} / \mathrm{C}$, $+405 \mathrm{C} / \mathrm{G}$, and $+936 \mathrm{C} / \mathrm{T}$ polymorphisms was associated with breast cancer risk in Iranian population [38].

$V E G F \quad-460 \mathrm{C} /+405 \mathrm{G} /+936 \mathrm{~T}$ haplotype was associated with decreased risk of lung cancer in Koreans [59] and increased risk of esophageal adenocarcinoma in Caucasian [60]. The TGC haplotype of $V E G F-460 \mathrm{C} / \mathrm{T},+405 \mathrm{C} / \mathrm{G}$ and $+936 \mathrm{C} / \mathrm{T}$ polymorphism was significantly associated with decreased risk of adenocarcinoma among male non-small cell lung cancer patients [61]. In Turkish population, VEGF $-2578 \mathrm{~A} /+936 \mathrm{~T} /-460 \mathrm{~T}$ haplotype has been reported to be associated with increased risk of colorectal cancer [62]. In Tunisians, CIC haplotype of $V E G F-2578 \mathrm{C} / \mathrm{A}$, $-2549 \mathrm{I} / \mathrm{D}$ and $+936 \mathrm{C} / \mathrm{T}$ polymorphisms was associated with increased risk of urothelial bladder cancer [63].

There are some studies from India on different diseases showing association of VEGF haplotypes with disease risk. The CTIG haplotype of $V E G F-2578 \mathrm{C} / \mathrm{A}$, $-7 \mathrm{C} / \mathrm{T},-2549 \mathrm{I} / \mathrm{D}$, and $-1001 \mathrm{G} / \mathrm{C}$ polymorphisms was associated with increased risk of bladder cancer [64] whereas TACI haplotype of $V E G F+936 \mathrm{C} / \mathrm{T},-1154 \mathrm{G} / \mathrm{A}$, $-2578 \mathrm{C} / \mathrm{A}$ and $-2549 \mathrm{I} / \mathrm{D}$ polymorphisms was associated with increased risk of end stage renal disease [65]. Haplotypes CGCC and CGGC of VEGF -460T/C, -1154G/A, $+405 \mathrm{C} / \mathrm{G}$, and $+936 \mathrm{C} / \mathrm{T}$ polymorphism were associated with aggressiveness of disease in epithelial ovarian cancer patients [66]. No association of $V E G F+405 C / G$ 
and $+936 \mathrm{C} / \mathrm{T}$ haplotypes with lung cancer risk has been reported in Kashmiri patients [67].

In the present study, CDTCCC haplotype was significantly associated with reduced risk of breast cancer in pre menopausal as well as in post menopausal patients when compared with pre and post menopausal controls. The breast cancer risk has also been reported to be modulated by menopause [68]. Estrogen exposure has been described as an important risk factor for breast cancer development and progression [69]. It has been documented that estrogen modulates angiogenesis via effects on endothelial cells under both physiologic and pathologic conditions [70]. Association of VEGF $-460 \mathrm{~T} /+405 \mathrm{G} /+936 \mathrm{~T}$ haplotype with reduced risk of breast cancer has been reported in Chinese premenopausal women [47]. Among post-menopausal breast cancer patients, CCCCC haplotype of $V E G F-2578 \mathrm{C} /$ $\mathrm{A},-2489 \mathrm{C} / \mathrm{T},-460 \mathrm{~T} / \mathrm{C},+405 \mathrm{C} / \mathrm{G}$ and $-7 \mathrm{C} / \mathrm{T}$ polymorphisms was associated with reduced risk of distant metastases [71].

The CDTCCC haplotype was significantly associated with decrease risk of breast cancer in obese as well as in non obese patients compared to obese and non obese controls where as CDTGCC haplotype was significantly associated with increased risk of breast cancer in premenopausal obese patients. About $75.2 \%$ of patients and $72 \%$ of controls were obese in the present study. It has been hypothesized that hormonal mechanisms and metabolic factors are involved in the link between obesity and breast cancer. Insulin resistance and hyperinsulinemia have been reported to be associated with increased breast cancer risk and with worst prognosis in both pre and post menopausal women [72-74]. In mouse model, it has been demonstrated that over expression of VEGFA in adipose tissue provide protection against high fat diet induced obesity and insulin sensitivity [75, 76]. It has been documented that angiogenesis plays an important role in the regulation of adipogenesis [77]. VEGF has been described as an important angiogenic factor in adipose tissue and it regulates the development of new vessels required for the expansion of adipose tissue [76, 78]. It has been reported that adiponectin, a regulator of insulin resistance block angiogenesis by increasing the expression of TP53 and decreasing the expression of $V E G F[79]$.

In the present study we predicted that $V E G F-2578 \mathrm{~A}$ allele of $V E G F-2578 \mathrm{C} / \mathrm{A}$ polymorphism abolished the binding site of GATA-2 transcription factor. The GATA family of transcription factors is regulator of gene expression in hematopoietic cells [80, 81]. Correlation of reduced GATA binding promoter activity has been documented with attenuation of VEGF mediated signaling [82]. G allele of $V E G F+405 C / G$ polymorphism created the binding site of MZF1 transcription factor. MZF1 transcription factor has been reported to be involved in transcriptional regulation during myelopoiesis [83]. Disruption of MZF1 transcription factor binding site by VEGF-634C $(+405 \mathrm{C})$ allele has also been reported in peripheral blood mononuclear cells [15]. It has been reported that substitution of $\mathrm{C}$ by $\mathrm{G}$ at +405 position in 5'-UTR may affect internal ribosome entry site (IRES) and increases the transcription of large isoform of VEGFA [84].

Polymorphisms of VEGFA have been reported to be associated with efficacy and toxicity of anti-VEGF agents $[41,85,86]$. Haplotype $-460 \mathrm{~T} /+405 \mathrm{C} /+936 \mathrm{C}$ haplotype was associated with better survival among Chinese breast cancer patients [87]. VEGF -2578A/-1154G/+405G haplotype was associated with marginally improved prognosis whereas haplotype $-2578 \mathrm{C} /-1154 \mathrm{G} /+405 \mathrm{G}$ was significantly associated with adverse prognosis in HER2 positive breast cancer patients [88]. Apart from breast cancer, correlation of $V E G F$ haplotypes with therapy response has also been documented in other cancer types. The CACC haplotype of $V E G F-460 \mathrm{~T} / \mathrm{C},-116 \mathrm{G} / \mathrm{A},+405 \mathrm{C} / \mathrm{G}$, and $+936 \mathrm{C} / \mathrm{T}$ polymorphism was significantly associated with worse survival in Korean gastric cancer patients [89]. In esophageal cancer, CGC haplotype of $V E G F-460 \mathrm{~T} / \mathrm{C}$, $+405 \mathrm{C} / \mathrm{G}$ and $+936 \mathrm{C} / \mathrm{T}$ polymorphism was associated with poorer outcome as compared to other haplotypes [90]. The AGCGC haplotype of $V E G F-2578 \mathrm{C} / \mathrm{A}$, $-1154 \mathrm{G} / \mathrm{A},-460 \mathrm{~T} / \mathrm{C},+405 \mathrm{G} / \mathrm{C}$ and $+936 \mathrm{C} / \mathrm{T}$ polymorphisms was found to be associated with improved progression-free survival in epithelial ovarian cancer patients [91]. Haplotype $-2578 \mathrm{C} /-460 \mathrm{~T} /+405 \mathrm{C} /+936 \mathrm{C}$ and $-2578 \mathrm{C} /-460 \mathrm{~T} /+405 \mathrm{C} /+936 \mathrm{~T}$ was associated with inferior response rate in metastatic colorectal cancer patients to first line XELOX treatment [92]. Thus, assessment of haplotypes of $V E G F$ polymorphisms may have implications for aggressiveness and selection of patients suitable for anti-VEGF therapy in context of previously reported literature. The VEGF haplotypes in independent cohorts are insightful for identification of cancer risk.

\section{Conclusions}

We report for the first time that CDTCCC and CDTGCC haplotypes of $V E G F-2578 \mathrm{C} / \mathrm{A},-2549 \mathrm{I} / \mathrm{D},-460 \mathrm{~T} / \mathrm{C}$, $+405 \mathrm{C} / \mathrm{G},-7 \mathrm{C} / \mathrm{T}$ and $+936 \mathrm{C} / \mathrm{T}$ polymorphisms were significantly associated with breast cancer risk in NorthWest Indians. Further studies on multiethnic groups with larger sample size are required to confirm our results.

\section{Abbreviations}

VEGF: Vascular endothelial growth factor; UTR: Untranslated region; OR: Odds ratio. 


\section{Supplementary Information}

The online version contains supplementary material available at https://doi. org/10.1186/s12920-021-01060-4.

Additional file 1. In silico pathway analysis based on chromosomal instability in breast cancer patients.

\section{Acknowledgements}

We thank the patients and the healthy control individuals for their participation.

\section{Authors' contributions}

KG and VS conceptualized and designed the study. RK and KG performed the experiments. KG and VS analyzed the results and prepared the manuscript. MM, MS, MSU and NRS did clinical diagnosis and histopathological classification of patients and also helped in collection of blood samples of breast cancer patients. All authors read and approved the final manuscript.

\section{Funding}

This study was supported by the DBT grant BT/PR 13252/GBD/27/236/2009 and DST-PURSE grant sanctioned to VS and KG. The funders had no role in the designing of the study or in the collection of samples, analysis of data or preparation of the manuscript

\section{Availability of data and materials}

All data generated in this study is included in Additional file 1:Table S1.

\section{Declarations}

\section{Ethics approval and consent to participate}

This study was approved by the Institutional Ethics Committee of Guru Nanak Dev University, Amritsar, Punjab, India. The consent form was in English as well as in local language of the region. The literate subjects gave a written informed consent with a signature. The illiterate subjects have their consent with a thumb impression on the form in presence of a witness (their relative or accompanying person).

\section{Consent for publication}

Not applicable.

\section{Competing interests}

Kamlesh Guleria, corresponding author and co-author Vasudha Sambyal are Associate Editors of BMC Medical Genomics Journal. Rest of the other authors declare that they have no competing interests.

\section{Author details \\ ${ }^{1}$ Human Cytogenetics Laboratory, Department of Human Genetics, Guru Nanak Dev University, Amritsar 143005, Punjab, India. ${ }^{2}$ Department of Pathol- ogy, Sri Guru Ram Das Institute of Medical Sciences and Research, Amritsar, Punjab, India. ${ }^{3}$ Department of Radiotherapy, Sri Guru Ram Das Institute of Medical Sciences and Research, Amritsar, Punjab, India. ${ }^{4}$ Department of Sur- gery, Sri Guru Ram Das Institute of Medical Sciences and Research, Amritsar, Punjab, India.}

Received: 26 November 2020 Accepted: 18 August 2021 Published online: 24 August 2021

\section{References}

1. Hanahan D, Weinberg RA. The hallmarks of cancer. Cell. 2000;100(1):57-70.

2. Hanahan D, Folkman J. Patterns and emerging mechanisms of the angiogenic switch during tumorigenesis. Cell. 1996;86(3):353-64.

3. Ferrara N, Davis-Smyth T. The biology of vascular endothelial growth factor. Endocr Rev. 1997;18(1):4-25.

4. Carmeliet P. Mechanisms of angiogenesis and arteriogenesis. Nat Med. 2000;6(4):389-95.
5. Ferrara N. Vascular endothelial growth factor: molecular and biological aspects. Curr Top Microbiol Immunol. 1999;237:1-30.

6. Yoshiji H, Kuriyama S, Yoshii J, Ikenaka Y, Noguchi R, Hicklin DJ, Wu Y, Yanase K, Namisaki T, Kitade M, Yamazaki M. Halting the interaction between vascular endothelial growth factor and its receptors attenuates liver carcinogenesis in mice. Hepatology. 2004;39(6):1517-24.

7. Roy H, Bhardwaj S, Ylä-Herttuala S. Biology of vascular endothelial growth factors. FEBS Lett. 2006;580(12):2879-87.

8. Dvorak HF, Brown LF, Detmar M, Dvorak AM. Vascular permeability factor/vascular endothelial growth factor, microvascular hyperpermeability, and angiogenesis. Am J Pathol. 1995;146(5):1029.

9. Kim I, Moon SO, Kim SH, Kim HJ, Koh YS, Koh GY. Vascular endothelial growth factor expression of intercellular adhesion molecule 1 (ICAM-1), vascular cell adhesion molecule 1 (VCAM-1), and E-selectin through nuclear factor-KB activation in endothelial cells. J Biol Chem. 2001;276(10):7614-20.

10. Reinders ME, Fang JC, Wong W, Ganz P, Briscoe DM. Expression patterns of vascular endothelial growth factor in human cardiac allografts: association with rejection. Transplantation. 2003;76(1):224-30.

11. Ferrara N. Vascular endothelial growth factor: basic science and clinical progress. Endocr Rev. 2004;25(4):581-611.

12. Kimura Y, Morohashi S, Yoshizawa T, Suzuki T, Morohashi H, Sakamoto Y, Koyama M, Murata A, Kijima H, Hakamada K. Clinicopathological significance of vascular endothelial growth factor, thymidine phosphorylase and microvessel density in colorectal cancer. Mol Med Rep. 2016;13(2):1551-7.

13. Vincenti V, Cassano C, Rocchi M, Persico MG. Assignment of the vascular endothelial growth factor gene to human chromosome 6p21. 3. Circulation. 1996;93(8):1493-5.

14. Brogan IJ, Khan N, Isaac K, Hutchinson JA, Pravica V, Hutchinson IV. Novel polymorphisms in the promoter and $5^{\prime}$ UTR regions of the human vascular endothelial growth factor gene. Hum Immunol. 1999:60(12):1245-9.

15. Watson CJ, Webb NJ, Bottomley MJ, Brenchley PE. Identification of polymorphisms within the vascular endothelial growth factor (VEGF) gene: correlation with variation in VEGF protein production. Cytokine. 2000;12(8):1232-5.

16. Akiri G, Nahari D, Finkelstein Y, Le SY, Elroy-Stein O, Levi BZ. Regulation of vascular endothelial growth factor (VEGF) expression is mediated by internal initiation of translation and alternative initiation of transcription. Oncogene. 1998;17(2):227-36.

17. Huez I, Créancier L, Audigier S, Gensac MC, Prats AC, Prats H. Two independent internal ribosome entry sites are involved in translation initiation of vascular endothelial growth factor mRNA. Mol Cell Biol. 1998;18(11):6178-90.

18. Taylor JG, Choi EH, Foster CB, Chanock SJ. Using genetic variation to study human disease. Trends Mol Med. 2001;7(11):507-12.

19. Renner W, Kotschan S, Hoffmann C, Obermayer-Pietsch B, Pilger E. A common $936 \mathrm{C} / \mathrm{T}$ mutation in the gene for vascular endothelial growth factor is associated with vascular endothelial growth factor plasma levels. J Vasc Res. 2000;37(6):443-8.

20. Awata T, Inoue K, Kurihara S, Ohkubo T, Watanabe M, Inukai K, Inoue I, Katayama S. A common polymorphism in the $5^{\prime}$-untranslated region of the VEGF gene is associated with diabetic retinopathy in type 2 diabetes. Diabetes. 2002;51(5):1635-9.

21. Mohammadi M, Ollier WE, Hutchinson IV. A functional association study of VEGF gene promoter polymorphisms with VEGF expression by stimulated pbm cells. Hum Immunol. 2003;10(64):S125.

22. Stevens A, Soden J, Brenchley PE, Ralph S, Ray DW. Haplotype analysis of the polymorphic human vascular endothelial growth factor gene promoter. Can Res. 2003;63(4):812-6.

23. Adams J, Carder PJ, Downey S, Forbes MA, MacLennan K, Allgar V, Kaufman S, Hallam S, Bicknell R, Walker JJ, Cairnduff F. Vascular endothelial growth factor (VEGF) in breast cancer: comparison of plasma, serum, and tissue VEGF and microvessel density and effects of tamoxifen. Can Res. 2000;60(11):2898-905.

24. Gasparini G. Prognostic value of vascular endothelial growth factor in breast cancer. Oncologist. 2000;5:37-44.

25. Yoshiji H, Gomez DE, Shibuya M, Thorgeirsson UP. Expression of vascular endothelial growth factor, its receptor, and other angiogenic factors in human breast cancer. Can Res. 1996:56(9):2013-6. 
26. Guidi AJ, Schnitt SJ, Fischer L, Tognazzi K, Harris JR, Dvorak HF, Brown LF. Vascular permeability factor (vascular endothelial growth factor) expression and angiogenesis in patients with ductal carcinoma in situ of the breast. Cancer. 1997;80(10):1945-53.

27. Koukourakis MI, Papazoglou D, Giatromanolaki A, Bougioukas G, Maltezos E, Siviridis E. VEGF gene sequence variation defines VEGF gene expression status and angiogenic activity in non-small cell lung cancer. Lung Cancer. 2004;46(3):293-8.

28. Ferrara N, Gerber HP, LeCouter J. The biology of VEGF and its receptors. Nat Med. 2003;9(6):669-76.

29. Willett CG, Boucher Y, Di Tomaso E, Duda DG, Munn LL, Tong RT, Chung DC, Sahani DV, Kalva SP, Kozin SV, Mino M. Direct evidence that the VEGFspecific antibody bevacizumab has antivascular effects in human rectal cancer. Nat Med. 2004;10(2):145-7.

30. Jain RK. Antiangiogenic therapy for cancer: current and emerging concepts. Oncology (Williston Park). 2005;19(4 Suppl 3):7-16.

31. Clark AG. The role of haplotypes in candidate gene studies. Genet Epidemiol. 2004;27(4):321-33.

32. Kapahi R, Manjari M, Uppal MS, Singh NR, Sambyal V, Guleria K. Association of - 2549 insertion/deletion polymorphism of vascular endothelial growth factor with breast cancer in North Indian patients. Genet Test Mol Biomarkers. 2013;17(3):242-8.

33. Adeli K, Ogbonna G. Rapid purification of human DNA from whole blood for potential application in clinical chemistry laboratories. Clin Chem. 1990;36(2):261-4.

34. Kapahi R, Manjari M, Sudan M, Uppal MS, Singh NR, Sambyal V, Guleria K. Association of $+405 C>G$ and $+936 C>T$ polymorphisms of the vascular endothelial growth factor gene with sporadic breast cancer in North Indians. Asian Pac J Cancer Prev. 2014;15(1):257-63.

35. Kapahi R, Guleria K, Sambyal V, Manjari M, Sudan M, Uppal MS, Singh NR. Association of VEGF and VEGFR1 polymorphisms with breast cancer risk in North Indians. Tumor Biol. 2015;36(6):4223-34.

36. Sole X, Guino E, Valls J, Iniesta R, Moreno V. SNPStats: a web tool for the analysis of association studies. Bioinformatics. 2006;22(15):1928-9.

37. Al Balawi IA, Mir R, Abu-Duhier FM. Potential impact of vascular endothelial growth factor gene variation $(-2578 C>A)$ on breast cancer susceptibility in Saudi Arabia: a case-control study. Asian Pac J Cancer Prev. 2018;19(4):1135

38. Rezaei M, Hashemi M, Sanaei S, Mashhadi MA, Taheri M. Association between vascular endothelial growth factor gene polymorphisms with breast cancer risk in an Iranian population. Breast Cancer (Auckl). 2016:10:85-91.

39. Rahoui J, Laraqui A, Sbitti Y, Touil N, Ibrahimi A, Ghrab B, Al Bouzidi A, Rahali DM, Dehayni M, Ichou M, Zaoui F. Investigating the association of vascular endothelial growth factor polymorphisms with breast cancer: a Moroccan case-control study. Med Oncol. 2014;31(9):193.

40. Sa-Nguanraksa D, Chuangsuwanich T, Pongpruttipan T, Kummalue T, Rojananin S, Ratanawichhitrasin A, Prasarttong-Osoth P, Chuthatisith S, Pisarnturakit P, Aeumrithaicharoenchok W, Rushatamukayanunt P. Vascular endothelial growth factor-634G/C polymorphism is associated with increased breast cancer risk and aggressiveness. Mol Med Rep. 2013;8(4):1242-50.

41. Schneider BP, Radovich M, Sledge GW, Robarge JD, Li L, Storniolo AM Lemler S, Nguyen AT, Hancock BA, Stout M, Skaar T. Association of polymorphisms of angiogenesis genes with breast cancer. Breast Cancer Res Treat. 2008;111(1):157-63.

42. Langsenlehner T, Langsenlehner U, Renner W, Krippl P, Mayer R, Wascher TC, Kapp KS. Single nucleotide polymorphisms and haplotypes in the gene for vascular endothelial growth factor and risk of prostate cancer. Eur J Cancer. 2008;44(11):1572-6.

43. Pharoah PD, Antoniou AC, Easton DF, Ponder BA. Polygenes, risk prediction, and targeted prevention of breast cancer. N Engl J Med. 2008;358(26):2796-803.

44. Jacobs EJ, Feigelson HS, Bain EB, Brady KA, Rodriguez C, Stevens VL, Patel AV, Thun MJ, Calle EE. Polymorphisms in the vascular endothelial growth factor gene and breast cancer in the Cancer Prevention Study II cohort. Breast Cancer Res. 2006;8(2):R22.

45. Jin Q, Hemminki K, Enquist K, Lenner P, Grzybowska E, Klaes R, Henriksson R, Chen B, Pamula J, Pekala W, Zientek H. Vascular endothelial growth factor polymorphisms in relation to breast cancer development and prognosis. Clin Cancer Res. 2005;11(10):3647-53.
46. Balasubramanian SP, Cox A, Cross SS, Higham SE, Brown NJ, Reed MW. Influence of VEGF-A gene variation and protein levels in breast cancer susceptibility and severity. Int J Cancer. 2007;121(5):1009-16.

47. Kataoka N, Cai Q, Wen W, Shu XO, Jin F, Gao YT, Zheng W. Populationbased case-control study of VEGF gene polymorphisms and breast cancer risk among Chinese women. Cancer Epidemiol Biomarkers Prev. 2006;15(6):1148-52

48. James R, Ramesh G, Krishnamoorthy L, Bhagat R, Chadaga S, Deshmane V, Ramaswamy G. Prevalence of + 405G>C,-1154G> A vascular endothelial growth factor polymorphism in breast cancer. Indian J Clin Biochem. 2014;29(1):21-8.

49. Rani J, Rahul B, Ramesh G, Krishnamoorthy L, Shilpa C, Ramaswamy G, Deshmane $V$. Association of vascular endothelial growth factor single nucleotide polymorphisms on the prognosis of breast cancer patients. Indian J Cancer. 2014;51(4):512.

50. Luo T, Chen L, He P, Hu QC, Zhong XR, Sun Y, Yang YF, Tian TL, Zheng $H$. Vascular endothelial growth factor (VEGF) gene polymorphisms and breast cancer risk in a Chinese population. Asian Pac J Cancer Prev. 2013;14(4):2433-7.

51. Oliveira C, Lourenço GJ, Silva PM, Cardoso-Filho C, Favarelli MH, Gonçales NS, Gurgel MS, Lima CS. Polymorphisms in the 5'-and 3'-untranslated region of the VEGF gene and sporadic breast cancer risk and clinicopathologic characteristics. Tumor Biol. 2011;32(2):295-300.

52. Absenger G, Szkandera J, Stotz M, Pichler M, Winder T, Langsenlehner T, Langsenlehner U, Samonigg H, Renner W, Gerger A. A common and functional gene variant in the vascular endothelial growth factor a predicts clinical outcome in early-stage breast cancer. Mol Carcinog. 2013;52(S1):96-102.

53. Rodrigues P, Furriol J, Tormo E, Ballester S, Lluch A, Eroles P. The singlenucleotide polymorphisms + 936 C/T VEGF and- 710 C/T VEGFR1 are associated with breast cancer protection in a Spanish population. Breast Cancer Res Treat. 2012;133(2):769-78.

54. Lin GT, Tseng HF, Yang CH, Hou MF, Chuang LY, Tai HT, Tai MH, Cheng $\mathrm{YH}$, Wen CH, Liu CS, Huang CJ. Combinational polymorphisms of seven CXCL12-related genes are protective against breast cancer in Taiwan. OMICS. 2009;13(2):165-72.

55. Jakubowska A, Gronwald J, Menkiszak J, Górski B, Huzarski T, Byrski T, Edler L, Lubiński J, Scott RJ, Hamann U. The VEGF_936_C> T 3' UTR polymorphism reduces BRCA1-associated breast cancer risk in Polish women. Cancer Lett. 2008;262(1):71-6.

56. Eroğlu A, Öztürk A, Cam R, Akar N. Vascular endothelial growth factor gene $936 \mathrm{C} / \mathrm{T}$ polymorphism in breast cancer patients. Med Oncol. 2008;25(1):54-5.

57. Krippl P, Langsenlehner U, Renner W, Yazdani-Biuki B, Wolf G, Wascher TC, Paulweber B, Haas J, Samonigg H. A common 936 C/T gene polymorphism of vascular endothelial growth factor is associated with decreased breast cancer risk. Int J Cancer. 2003;106(4):468-71.

58. Kidd LR, Brock GN, VanCleave TT, Benford ML, Lavender NA, Kruer TL, Wittliff JL. Angiogenesis-associated sequence variants relative to breast cancer recurrence and survival. Cancer Causes Control. 2010;21(10):1545-57.

59. Lee SJ, Lee SY, Jeon HS, Park SH, Jang JS, Lee GY, Son JW, Kim CH, Lee WK, Kam S, Park RW. Vascular endothelial growth factor gene polymorphisms and risk of primary lung cancer. Cancer Epidemiol Biomarkers Prev. 2005; 14(3):571-5

60. Zhai R, Liu G, Asomaning K, Su L, Kulke MH, Heist RS, Nishioka NS, Lynch TJ, Wain JC, Lin X, Christiani DC. Genetic polymorphisms of VEGF, interactions with cigarette smoking exposure and esophageal adenocarcinoma risk. Carcinogenesis. 2008;29(12):2330-4.

61. Zhai R, Liu G, Zhou W, Su L, Heist RS, Lynch TJ, Wain JC, Asomaning K, Lin X, Christiani DC. Vascular endothelial growth factor genotypes, haplotypes, gender, and the risk of non-small cell lung cancer. Clin Cancer Res. 2008;14(2):612-7.

62. Jannuzzi AT, Özhan G, Yanar HT, Alpertunga B. VEGF gene polymorphisms and susceptibility to colorectal cancer. Genet Test Mol Biomarkers. 2015;19(3):133-7.

63. Ben Wafi S, Kallel A, Ben Fradj MK, Sallemi A, Ben Rhouma S, Ben Halima M, Sanhaji H, Nouira Y, Jemaa R, Feki M. Haplotype-based association of Vascular Endothelial Growth Factor gene polymorphisms with urothelial bladder cancer risk in Tunisian population. J Clin Lab Anal. 2018;32(9):e22610. 
64. Jaiswal PK, Tripathi N, Shukla A, Mittal RD. Association of single nucleotide polymorphisms in vascular endothelial growth factor gene with bladder cancer risk. Med Oncol. 2013;30(2):509.

65. Prakash S, Prasad N, Sharma RK, Faridi RM, Agrawal S. Vascular endothelial growth factor gene polymorphisms in North Indian patients with end stage renal disease. Cytokine. 2012;58(2):261-6.

66. Janardhan B, Vaderhobli S, Bhagat R, Chennagiri Srinivasamurthy P, Venketeshiah Reddihalli P, Gawari R, Krishnamoorthy L. Investigating impact of vascular endothelial growth factor polymorphisms in epithelial ovarian cancers: a study in the Indian population. PLoS ONE. 2015;10(7):e0131190.

67. Naikoo NA, Afroze D, Rasool R, Shah S, Ahangar AG, Bhat IA, Qasim I, Siddiqi MA, Shah ZA. SNP and haplotype analysis of vascular endothelial growth factor (VEGF) gene in lung cancer patients of Kashmir. Asian Pac J Cancer Prev. 2017;18(7):1799.

68. Mohanty SS, Mohanty PK. Obesity as potential breast cancer risk factor for postmenopausal women. Genes Dis. 2019;8:117-23.

69. Lapidus RG, Nass SJ, Davidson NE. The loss of estrogen and progesterone receptor gene expression in human breast cancer. J Mammary Gland Biol Neoplasia. 1998;3(1):85-94.

70. Losordo DW, Isner JM. Estrogen and angiogenesis: a review. Arterioscler Thromb Vasc Biol. 2001;21(1):6-12

71. Langsenlehner U, Hofmann G, Renner W, Gerger A, Krenn-Pilko S, Thurner EM, Krippl P, Langsenlehner T. Association of vascular endothelial growth factor-a gene polymorphisms and haplotypes with breast cancer metastases. Acta Oncol. 2015;54(3):368-76.

72. Goodwin PJ, Ennis M, Pritchard KI, Trudeau ME, Koo J, Madarnas Y, Hartwick W, Hoffman B, Hood N. Fasting insulin and outcome in earlystage breast cancer: results of a prospective cohort study. J Clin Oncol. 2002;20(1):42-51.

73. Morimoto LM, White E, Chen Z, Chlebowski RT, Hays J, Kuller L, Lopez AM, Manson J, Margolis KL, Muti PC, Stefanick ML. Obesity, body size, and risk of postmenopausal breast cancer: the Women's Health Initiative (United States). Cancer Causes Control. 2002;13(8):741-51.

74. Schairer C, Hill D, Sturgeon SR, Fears T, Pollak M, Mies C, Ziegler RG, Hoover RN, Sherman ME. Serum concentrations of IGF-I, IGFBP-3 and c-peptide and risk of hyperplasia and cancer of the breast in postmenopausal women. Int J Cancer. 2004;108(5):773-9.

75. Elias I, Franckhauser S, Ferré T, Vilà L, Tafuro S, Muñoz S, Roca C, Ramos D, Pujol A, Riu E, Ruberte J. Adipose tissue overexpression of vascular endothelial growth factor protects against diet-induced obesity and insulin resistance. Diabetes. 2012;61(7):1801-13.

76. Sun K, Asterholm IW, Kusminski CM, Bueno AC, Wang ZV, Pollard JW, Brekken RA, Scherer PE. Dichotomous effects of VEGF-A on adipose tissue dysfunction. Proc Natl Acad Sci. 2012;109(15):5874-9.

77. Xue Y, Petrovic N, Cao R, Larsson O, Lim S, Chen S, Feldmann HM, Liang Z, Zhu Z, Nedergaard J, Cannon B. Hypoxia-independent angiogenesis in adipose tissues during cold acclimation. Cell Metab. 2009;9(1):99-109.

78. Cao Y. Adipose tissue angiogenesis as a therapeutic target for obesity and metabolic diseases. Nat Rev Drug Discov. 2010;9(2):107-15.

79. Khan S, Shukla S, Sinha S, Meeran SM. Role of adipokines and cytokines in obesity-associated breast cancer: therapeutic targets. Cytokine Growth Factor Rev. 2013;24(6):503-13.

80. Tsai FY, Keller G, Kuo FC, Weiss M, Chen J, Rosenblatt M, Alt FW, Orkin SH. An early haematopoietic defect in mice lacking the transcription factor GATA-2. Nature. 1994;371(6494):221-6.
81. Shimizu R, Yamamoto M. Gene expression regulation and domain function of hematopoietic GATA factors. Semin Cell Dev Biol. 2005:16(1):129-36.

82. Minami T, Murakami T, Horiuchi K, Miura M, Noguchi T, Miyazaki J, Hamakubo T, Aird WC, Kodama T. Interaction between hex and GATA transcription factors in vascular endothelial cells inhibits flk-1/KDRmediated vascular endothelial growth factor signaling. J Biol Chem. 2004;279(20):20626-35.

83. Lenny N, Westendorf JJ, Hiebert SW. Transcriptional regulation during myelopoiesis. Mol Biol Rep. 1997;24(3):157.

84. Huez I, Bornes S, Bresson D, Créancier L, Prats H. New vascular endothelial growth factor isoform generated by internal ribosome entry site-driven CUG translation initiation. Mol Endocrinol. 2001;15(12):2197-210.

85. Etienne-Grimaldi MC, Formento P, Degeorges A, Pierga JY, Delva R, Pivot $X$, Dalenc F, Espié M, Veyret C, Formento JL, Francoual M. Prospective analysis of the impact of VEGF-A gene polymorphisms on the pharmacodynamics of bevacizumab-based therapy in metastatic breast cancer patients. Br J Clin Pharmacol. 2011;71(6):921-8.

86. Formica V, Palmirotta R, Del Monte G, Savonarola A, Ludovici G, De Marchis ML, Grenga I, Schirru M, Guadagni F, Roselli M. Predictive value of VEGF gene polymorphisms for metastatic colorectal cancer patients receiving first-line treatment including fluorouracil, irinotecan, and bevacizumab. Int J Colorectal Dis. 2011;26(2):143-51.

87. Lu H, Shu XO, Cui Y, Kataoka N, Wen W, Cai Q, Ruan ZX, Gao YT, Zheng W. Association of genetic polymorphisms in the VEGF gene with breast cancer survival. Can Res. 2005;65(12):5015-9.

88. Maae E, Andersen RF, Steffensen KD, Jakobsen EH, Brandslund I, Sørensen FB, Jakobsen A. Prognostic impact of VEGFA germline polymorphisms in patients with HER2-positive primary breast cancer. Anticancer Res. 2012;32(9):3619-27.

89. Kim JG, Sohn SK, Chae YS, Cho YY, Bae HI, Yan G, Park JY, Lee MH, Chung HY, Yu W. Vascular endothelial growth factor gene polymorphisms associated with prognosis for patients with gastric cancer. Ann Oncol. 2007;18(6):1030-6.

90. Bradbury PA, Zhai R, Ma C, Xu W, Hopkins J, Kulke MJ, Asomaning K, Wang Z, Su L, Heist RS, Lynch TJ. Vascular endothelial growth factor polymorphisms and esophageal cancer prognosis. Clin Cancer Res. 2009;15(14):4680-5.

91. Steffensen KD, Waldstrøm M, Brandslund I, Jakobsen A. The relationship of VEGF polymorphisms with serum VEGF levels and progressionfree survival in patients with epithelial ovarian cancer. Gynecol Oncol. 2010;117(1):109-16.

92. Hansen TF, Spindler KG, Andersen RF, Lindebjerg J, Brandslund I, Jakobsen A. The predictive value of genetic variations in the vascular endothelial growth factor A gene in metastatic colorectal cancer. Pharmacogenomics J. 2011;11(1):53-60.

\section{Publisher's Note}

Springer Nature remains neutral with regard to jurisdictional claims in published maps and institutional affiliations.

\footnotetext{
Ready to submit your research? Choose BMC and benefit from:

- fast, convenient online submission

- thorough peer review by experienced researchers in your field

- rapid publication on acceptance

- support for research data, including large and complex data types

- gold Open Access which fosters wider collaboration and increased citations

- maximum visibility for your research: over $100 \mathrm{M}$ website views per year
}

At $\mathrm{BMC}$, research is always in progress.

Learn more biomedcentral.com/submissions 